\title{
Effects of different ammonium nitrate levels on the amounts of exchangeable soil magnesium and applied magnesium in eight mineral soils
}

\author{
RAILI JOKINEN \\ University of Helsinki, Department of Agricultural Chemistry, \\ SF-00710 HELSINKI, Finland
}

\begin{abstract}
Eight mineral soils $\left(\mathrm{pH}\left(\mathrm{CaCl}_{2}\right) 4.6-6.1\right.$, clay $4-65 \%$, org. C $1.9-5.7 \%$ ) were treated with ammonium nitrate and magnesium sulphate solutions adding 0,20 or $40 \mathrm{mg}$ mineral $\mathrm{N}$ and 0 or $4 \mathrm{mg} \mathrm{Mg}$ per $100 \mathrm{~g}$ soil. The soils were incubated for seven weeks at a constant temperature of $20^{\circ} \mathrm{C}$ and a $25 \%$ moisture level. After incubation, the exchangeable $\mathrm{Mg}$ was extracted with $1 \mathrm{M}$ neutral ammonium acetate.

The exchangeable magnesium content seemed to increase in some soils and to decrease in other soils with increasing ammonium nitrate amounts. The applied magnesium was fixed in a non-exchangeable form, especially at the highest ammonium nitrate level, in two clay soils taken from the rapakivi area of south-eastern Finland. In the other soils all applied magnesium was exchangeable irrespective of the amount of ammonium nitrate.
\end{abstract}

\section{Introduction}

A great part of the mineral $\mathrm{N}$ in compound $\mathrm{N}-\mathrm{P}-\mathrm{K}$ fertilizers is in the form of $\mathrm{NH}_{4}-\mathrm{N}$. According to several studies (e.g. Nommik 1957, Schachtschabel 1961, Kaila 1962), the mineral soils have the ability to fix applied $\mathrm{NH}_{4}{ }^{+}$in a non-exchangeable form. The cations $\mathrm{Ca}^{2+}$ or $\mathrm{Mg}^{2+}$ have no effect on this fixation (Nommiк 1957).

Only few studies on the effects of different mineral $\mathrm{N}$ levels on the exchangeable cation content of the soil are available (SIPPOLA et al. 1973). In laboratory studies on exchangeable cations a common practice is to treat the soil with $\mathrm{NH}_{4}{ }^{+}$acetate or chloride. The $\mathrm{NH}_{4}{ }^{+}-\mathrm{N}$ containing fertilizers may have the same effect, even though the $\mathrm{NH}_{4}{ }^{+}$concentration in the soil remains lower than in laboratory studies.

In a pot experiment, the apparent recovery of fertilizer $\mathrm{Mg}$ was low in some clay soils (JOKINEN 1981 a). The antagonism between $\mathrm{NH}_{4}{ }^{+}$and $\mathrm{Mg}^{2+}$ in the cation uptake by 
plants was assumed to be the main reason for this. The effects of ammonium nitrate on soil $\mathrm{Mg}$ and applied $\mathrm{Mg}$ were not studied.

The aim of the present incubation experiment was to study the effects of different ammonium nitrate levels on the exchangeable $\mathrm{Mg}$ content of eight mineral soils and on the amounts of exchangeable $\mathrm{Mg}$ applied with magnesium sulphate.

\section{Materials and methods}

Eight mineral soils were incubated at $20^{\circ} \mathrm{C}$ for seven weeks. The soil samples, three non-clay and five clay soils, represented the plough layer of cultivated soil from southern Finland. The same soils were used in an earlier pot experiment (JOKINEN 1981 a) and incubation experiment (JOKINEN 1981 b). The numbers and characteristics of the soils are given in the latter report. One of the soils, muddy silt (4), was not included in this study because of the too small amount of soil available.

The soils were air-dried and crushed to pass a $2-\mathrm{mm}$ sieve. For the experiment, 100 $\mathrm{g}$ soil was weighed into 0.5 litre plastic pots and treated with ammonium nitrate and magnesium sulphate adding the following amounts of $\mathrm{N}$ and $\mathrm{Mg}$ :

$\begin{array}{ll}\text { Symbol } & \text { Treatment } \\ \mathrm{N}_{1} \mathrm{Mg}_{0} & 20 \mathrm{mg} \mathrm{N} \\ \mathrm{N}_{1} \mathrm{Mg}_{1} & 20 \mathrm{mg} \mathrm{N}+4 \mathrm{mg} \mathrm{Mg} \\ \mathrm{N}_{2} \mathrm{Mg}_{0} & 40 \mathrm{mg} \mathrm{N} \\ \mathrm{N}_{2} \mathrm{Mg}_{1} & 40 \mathrm{mg} \mathrm{N}+4 \mathrm{mg} \mathrm{Mg}\end{array}$

The treatments without $\mathrm{N}$ fertilization $\left(\mathrm{N}_{0} \mathrm{Mg}_{0}\right.$ and $\left.\mathrm{N}_{0} \mathrm{Mg}_{1}\right)$ were common with the incubation experiment on liming and $\mathrm{Mg}$ fertilization (JOKINEN 1981 b). The fertilizer solutions were thoroughly mixed with the soil. Four replicates were made. Both experiments were incubated at the same time and in the same place. The moisture of the soils was maintained at $25 \%$ of the soil weight, adding de-ionized water as necessary. The pots were covered with perforated plastic film.
After incubation, the soils were air-dried at room temperature and repassed through a 2-mm sieve. The exchangeable $\mathrm{Mg}$ was extracted by $1 \mathrm{M}$ neutral ammonium acetate and exchange acidity $(\mathrm{Al}+\mathrm{H})$ by $1 \mathrm{M} \mathrm{KC1}$ (KaIla 1971). The amount of applied $\mathrm{Mg}$ found exchangeable in the soil was calculated as the difference $\mathrm{Mg}_{1}-\mathrm{Mg}_{0}$. The exchangeable $\mathrm{NH}_{4}{ }^{+}$was extracted with $0.25 \mathrm{M} \mathrm{K}_{2} \mathrm{SO}_{4}$ (soil : solution $=1: 10, \mathrm{w} / \mathrm{v}, 2 \mathrm{~h}$ ) and determined by destillation. The $\mathrm{NO}_{3}{ }^{-}$was determined from the same aliquot of extract after reduction with Devarda's alloy. The amounts of applied mineral $\mathrm{N}$ found in the soils were calculated as the differences $\mathrm{N}_{1}$ $\mathrm{N}_{0}$ and $\mathrm{N}_{2}-\mathrm{N}_{0}$.

\section{Results and discussion}

After seven weeks of incubation, almost all the mineral $\mathrm{N}\left(\mathrm{NH}_{4}{ }^{+}-\mathrm{N}+\mathrm{NO}_{3}{ }^{-}-\mathrm{N}\right)$ applied was found in the soils extractable in 0.25 $\mathrm{M} \mathrm{K}_{2} \mathrm{SO}_{4}$ at the $\mathrm{N}_{1}$ level. In finer fine sand (3), sandy clay (6) and silty clay (8), the nitrification of $\mathrm{NH}_{4}{ }^{+}-\mathrm{N}$ seemed to be complete, since the amount of $\mathrm{NO}_{3}{ }^{-}-\mathrm{N}$ increased in the same proportion. At the $\mathrm{N}_{2}$ level, the nitrification of applied $\mathrm{NH}_{4}{ }^{+}$was observed in silty clay (8) only, possibly because of the high amount of mineral $\mathrm{N}$ applied.

In finer fine sand (3) and in clays (6-9) without ammonium nitrate, the exchangeable $\mathrm{Mg}$ content seemed to be somewhat higher than with $\mathrm{N}$ (Table 1). Increased activity of micro-organisms in soils 3,6 and 8 by $\mathrm{N}$ fertilization was concluded on the basis of increased $\mathrm{NO}_{3}{ }^{-}-\mathrm{N}$ content during incubation. Some of the exchangeable $\mathrm{Mg}$ may be involved in the biological fixation. In fine sand (1) and silty clay (5), the exchangeable $\mathrm{Mg}$ content seemed to increase with increasing ammonium nitrate amounts. Some of the non-exchangeable $\mathrm{Mg}$ in these soils may become exchangeable without difficulty, e.g. by chemical weathering. This may explain the ability of ryegrass in the pot experiment to take up non-exchangeable $\mathrm{Mg}$ from fine sand (1). 
Table 1. Exchangeable $\mathrm{Mg}$ content, $\mathrm{mg} / 100 \mathrm{~g}$ soil, in eight mineral soils after seven weeks of incubation. $\left(\mathrm{Mg}_{0}=\right.$ without $\mathrm{Mg}$ fertilization. $\mathrm{Mg}_{1}=\mathrm{Mg}$ fertilization $4 \mathrm{mg} / 100 \mathrm{~g}$ soil).

\begin{tabular}{|c|c|c|c|c|c|c|}
\hline & \multicolumn{3}{|c|}{$\mathrm{Mg}_{0}$} & \multicolumn{3}{|c|}{$\mathrm{Mg}_{1}-\mathrm{Mg}_{0}$} \\
\hline & $\mathrm{N}_{0}$ & $\mathrm{~N}_{1}$ & $\mathrm{~N}_{2}$ & $\mathrm{~N}_{0}$ & $\mathrm{~N}_{1}$ & $\mathrm{~N}_{2}$ \\
\hline 1. Fine sand & $1.2^{\mathrm{a}}$ & $1.5^{b}$ & $1.6^{\mathrm{b}}$ & $4.3^{a}$ & $4.3^{\mathrm{a}}$ & $4.4^{\mathrm{a}}$ \\
\hline 2. Fine sand & $5.9^{a}$ & $6.0^{\mathrm{a}}$ & $6.1^{\mathrm{a}}$ & $4.5^{b}$ & $3.7^{\mathrm{a}}$ & $3.6^{a}$ \\
\hline 3. Finer fine sand & $16.0^{c}$ & $13.6^{\mathrm{a}}$ & $14.3^{b}$ & $3.8^{\mathrm{b}}$ & $4.0^{b}$ & $3.1^{\mathrm{a}}$ \\
\hline 5. Silty clay & $10.9^{a}$ & $11.4^{b}$ & $11.5^{b}$ & $3.9^{\mathrm{a}}$ & $4.1^{\mathrm{a}}$ & $4.1^{\mathrm{a}}$ \\
\hline 6. Sandy clay & $24.1^{\mathrm{a}}$ & $23.6^{a}$ & $23.9^{\mathrm{a}}$ & $4.7^{\mathrm{b}}$ & $3.0^{\mathrm{a}}$ & $2.4^{\mathrm{a}}$ \\
\hline 7. Sandy clay & $52.3^{\mathrm{a}}$ & $48.7^{a}$ & $49.2^{\mathrm{a}}$ & $4.4^{\mathrm{a}}$ & $4.6^{a}$ & $5.1^{\mathrm{a}}$ \\
\hline 8. Silty clay & $34.5^{b}$ & $32.6^{a}$ & $33.4^{\mathrm{ab}}$ & $4.4^{a}$ & $4.3^{\mathrm{a}}$ & $3.6^{\mathrm{a}}$ \\
\hline 9. Heavy clay & $77.0^{\mathrm{a}}$ & $75.5^{a}$ & $75.5^{\mathrm{a}}$ & $6.1^{\mathrm{a}}$ & $4.5^{\mathrm{a}}$ & $4.5^{\mathrm{a}}$ \\
\hline
\end{tabular}

Results of an individual soil with the same letter do not deviate significantly $\left(\mathrm{P}=5 \%\right.$ ). The datas of $\mathrm{Mg}_{0}$ and $\mathrm{Mg}_{1}-\mathrm{Mg}_{0}$ were studied separately by Duncan's new multiple range test.

Without ammonium nitrate the applied $\mathrm{Mg}$ (4 mg/100 g soil) was found exchangeable in all soils after incubation (Table 1). Considerable amounts of $\mathrm{Mg}$ were released from heavy clay (9) in the exchangeable form during incubation.

With ammonium nitrate the applied $\mathrm{Mg}$ was partly tied up by fine sand (2) and sandy clay (6) at both $\mathrm{N}$ levels and by finer fine sand (3) and silty clay (8) at the $\mathrm{N}_{2}$ level. The soils 6 and 8 originated from the rapakivi area of south-eastern Finland where, according to SipPOLA (1974), K-feldspar is more common than elsewhere in Finland. In these soils the fixation of $\mathrm{NH}_{4}{ }^{+}-\mathrm{N}$ into a non-exchangeable form seemed to be low because of the high $\mathrm{K}$ content (SCHERER 1982). Hence it is possible that applied $\mathrm{NH}_{4}{ }^{+}-\mathrm{N}$ contributed to the formation of nonexchangeable $\mathrm{Mg}$ compounds. In finer fine sand (3), the fixation of applied $\mathrm{Mg}$ in the non-exchangeable form may be a consequence of the formation of insoluble $\mathrm{Al}-\mathrm{Mg}$ compounds (HunSAKER and PRATT 1970), since the $1 \mathrm{M} \mathrm{KCl}$ extractable $\mathrm{Al}^{3+}$ content of this soil decreased with increasing amounts of ammonium nitrate. The content of $\mathrm{H}^{+}$ remained constant.
With increasing amounts of ammonium nitrate the reactions against applied $\mathrm{Mg}$ deviated in two clays (6 and 7) as well as in two silty clays (5 and 8 ). From soils 5 and $7 \mathrm{Mg}$ was released in the exchangeable form and in soils 6 and 8 the fixation of $\mathrm{Mg}$ in non-exchangeable form occured during incubation.

The apparent recovery of fertilizer $\mathrm{Mg}$ by ryegrass (total of 8 cuts) was for the mrapakivi» soils (6 and 8 ) very low at the $\mathrm{N}_{1}$ level (1.6\% and $0.4 \%$ ), but somewhat higher values were obtained at the $\mathrm{N}_{2}$ level $(13.6 \%$ and $39.7 \%$ ) in the pot experiment (JOKINEN 1981 a). Ryegrass seemed to be able to take up fixed $\mathrm{Mg}$ from these soils during the two growing seasons studied.

From the agricultural point of view the high amount of ammonium nitrate may have positive effects on the exchangeable $\mathrm{Mg}$ content of some soils. The applied $\mathrm{Mg}$ seemed to be fixed in the non-exchangeable form in some soils and this may contribute to the low recovery of fertilizer $\mathrm{Mg}$. The antagonism between $\mathrm{Mg}^{2+}$ and $\mathrm{NH}_{4}{ }^{+}$or $\mathrm{K}^{+}$in the cation uptake by plants is the main but not the only reason for the restricted $\mathrm{Mg}$ uptake. 


\section{References}

Hunsaker, V. E. \& Pratt, P. E. 1970. The formation of mixed magnesium-aluminum hydroxides in soil minerals. Soil Sci. Soc. Amer. Proc. 34: 813-816.

JOKINEN, R. 1981 a. Soil magnesium and fertilizer magnesium uptake by ryegrass on nine mineral soils at two ammonium nitrate levels I. Magnesium uptake. Ann. Agric. Fenn. 20: 231-243.

-1981 b. Effect of liming on the magnesium status of some mineral soils and on the fate of fertilizer magnesium. J. Scient. Agric. Soc. Finl. 53: 126-137.

KAllA, A. 1962. Fixation of ammonium in Finnish soils. J. Scient. Agric. Soc. Finl. 34: 107-114.

- 1971. Aluminium and acidity in Finnish soils. J. Scient. Agric. Soc. Finl. 43: 11-19.

Noммік, H. 1957. Fixation and defixation of ammonium in soils. Acta Agric. Scand. 7: 395-436.

\section{SELOSTUS}

\section{Ammoniumnitraatin vaikutus maan magnesiumin ja lannoituksena annetun magnesiumin uuttuvuuteen kahdeksasta kivennäismaasta}

\section{Raili Jokinen}

Helsingin yliopisto, maanviljelyskemian laitos, 00710 Helsinki 71

Muhituskokeena tehdyn tutkimuksen maat oli otettu viljeltyjen maiden muokkauskerroksesta eri puolilta Suomea.

$\begin{array}{cll}\begin{array}{c}\text { Maa } \\ \text { n:o }\end{array} & \text { Maalaji } & \text { Kunta } \\ 1 & \text { Karkea hieta } & \text { Ruukki } \\ 2 & \text { Karkea hieta } & \text { Mikkeli mlk } \\ 3 & \text { Hieno hieta } & \text { Toholampi } \\ 5 & \text { Hiesusavi } & \text { Laukaa } \\ 6 & \text { Hietasavi } & \text { Anjalankoski } \\ 7 & \text { Hietasavi } & \text { Vantaa } \\ 8 & \text { Hiesusavi } & \text { Anjalankoski } \\ 9 & \text { Aitosavi } & \text { Jokioinen }\end{array}$

Laboratoriossa kuivia ja jauhettuja maita lannoitettiin ammoniumnitraatti- ja magnesiumsulfaattiliuoksilla niin, että $100 \mathrm{~g}$ kohti maata lisăttiin seuraavat määrät typpeă $(\mathrm{N})$ ja magnesiumia $(\mathrm{Mg})$ :

$\begin{array}{ll}\mathrm{N}_{0} \mathrm{Mg}_{0} & \text { Ilman N } \\ \mathrm{N}_{0} \mathrm{Mg}_{1} & \text { Ilman N }+4 \mathrm{mg} \mathrm{Mg} \mathrm{(n.} 80 \mathrm{~kg} / \mathrm{ha}) \\ \mathrm{N}_{1} \mathrm{Mg}_{0} & 20 \mathrm{mg} \mathrm{N} \text { (n. } 400 \mathrm{~kg} / \mathrm{ha}) \\ \mathrm{N}_{1} \mathrm{Mg}_{1} & 20 \mathrm{mg} \mathrm{N}+4 \mathrm{mg} \mathrm{Mg} \\ \mathrm{N}_{2} \mathrm{Mg}_{0} & 40 \mathrm{mg} \mathrm{N} \\ \mathrm{N}_{2} \mathrm{Mg}_{1} & 40 \mathrm{mg} \mathrm{N}+4 \mathrm{mg} \mathrm{Mg}\end{array}$

SChachtschabel, P. 1961. Fixierung und Nachlieferung von Kalium- und Ammonium-Ionen. Landw. Forsch. Sonderh. 15: 29-47.

SCHerer, H. W. 1982. Fixed $\mathrm{NH}_{4}{ }^{+}-\mathrm{N}$ in relation to EUF-extractable K. Plant and Soil 64: 67-71.

Sippola, J. 1974. Mineral composition and its relation to texture and to some chemical properties in Finnish subsoils. Ann. Agric. Fenn. 13: 169-234.

-, Erviö, R. \& Eleveld, R. 1973. The effects of simultaneous addition of ammonium and potassium on their fixation in some Finnish soils. Ann. Agric. Fenn. 12: 185-189.

Ms received March 15, 1984
Maat kostutettiin ( $25 \%$ kosteus) ja niitä muhitettiin $20^{\circ} \mathrm{C}$ vakiolämpötilassa seitsemän viikkoa.

Ammoniumnitraatin lisääminen aiheutti muutamissa maissa (1, 2 ja 5) lievăn vaihtuvan magnesiumin mäărän lisäăntymisen mahdollisesti kemiallisen rapautumisen seurauksena (Taulukko). Toisissa maissa vaihtuvan magnesiumin mäără năytti văhenevän vilkastuneen pieneliötoiminnan aiheuttaman biologisen pidättymisen vuoksi.

Kaakkois-Suomen rapakivialueelta otetuissa savimaissa (6 ja 8) osa lannoituksena annetusta magnesiumista näytti pidättyvän vaihtumattomaan muotoon. Biologisen pidättymisen lisăksi maassa näyttäisi tapahtuvan kemiallista pidăttymistă vaikealiukoisiksi yhdisteiksi. Useimmissa koemaissa lannoituksena lisătty magnesium oli kaikki vaihtuvana, siis kasveille kảyttőkelpoisena, ammoniumnitraatin mäărästă riippumatta.

Aikaisemmin tämän tutkimuksen mailla tehdyssă astiakokeessa raiheinä otti vain pienen osan lannoituksena annetusta magnesiumista juuri niillä mailla, joilla tässä muhituskokeessa todettiin magnesiumin pidättymistä vaihtumattomaksi. Raiheinä kykeni ottamaan vaihtumatontakin magnesiumia. 